\title{
Optimizing Property Income in Transit Oriented Development: A Case Study of Jakarta TOD
}

\author{
Gunawan, Mohammed Ali Berawi", Mustika Sari \\ Department of Civil Engineering, Faculty of Engineering, University of Indonesia, Indonesia
}

Received March 3, 2020; Revised April 10, 2020; Accepted April 27, 2020

Copyright $\bigcirc 2020$ by authors, all rights reserved. Authors agree that this article remains permanently open access under the terms of the Creative Commons Attribution License 4.0 International License

\begin{abstract}
Transit-oriented development (TOD) can make a significant contribution to the development of Jabodebek Light Rail Transit (LRT) in Indonesia. The increase of property value affected by the existence of LRT station can be considered as one of the potential revenues for TOD projects. This study aims to estimate property income for housing, commercial, and office in the TOD-based areas. Interview is used to obtain the variable characteristics for the hedonic price modeling (HPM) suitability from the benchmark TOD areas with the case study TOD areas at the Jabodebek LRT line. The HPM coefficient of the value increase from the benchmark that has conformance characteristics with the case study will be used to calculate the magnitude of the increase of property value. It is found that due to the influence of the hedonic coefficient, the property income of Ciracas TOD is 414.5 billion rupiah with an internal rate of return (IRR) of $11.7 \%$, the property income of Bekasi Timur TOD is 84 billion rupiah with IRR of $11.01 \%$, the property income of Cibubur TOD is 152.97 billion rupiah with IRR of $19.51 \%$, and the property income of Jaticempaka TOD is 330.36 billion with IRR of $12.01 \%$.
\end{abstract}

Keywords Transit Oriented Development, Hedonic Price Modeling, Light Rail Transit

\section{Introduction}

The high mobility of people and goods in Jakarta as the capital city of Indonesia has not been able to correspond to the availability of safe and comfortable public transportation. Therefore, as a consequence, the numbers of private motor vehicles such as motorcycles and four-wheeled vehicles continue to grow each year rapidly, making this growth no longer proportional to the growth of road length.

Light Rail Transit (LRT) is one of the alternatives of highly integrated and suitable transportation modes [1] operated in Jakarta that will connect it to its satellite cities such as Bogor, Depok, and Bekasi.

In the development project of Jabodebek LRT with services across Jakarta, Bogor, Depok, and Bekasi, project financing is found to be a crucial problem as is usually the case with infrastructure projects in Indonesia [2]. In order to develop this transportation infrastructure project, the government is well aware of the significant costs needed for initial costs and operational and maintenance costs, which generally tend to burden the government fiscal budget [3]. Therefore, the project should come up with alternative sources of funding to avoid this situation. The role of the investors is very fundamental to be involved in the project so that the responsibility for project funding is not only borne by the government. However, in order to attract the investors' interests and trust, infrastructure projects should have a high feasibility value $[4,5]$, in which alternatives, ideas, elegant methods, and creative and innovative efforts to increase the functionality and benefits of the project are required [6].

The alternative to increasing the feasibility value of the projects, particularly in transport infrastructure projects is by elaborating them with a transport-oriented development (TOD) approach [7]. TOD is a city planning concept that is developed and popularized in the United States from the 1970 s to 1980 s as a response to the problem of urban congestion in the United States that grew rapidly at that time. The basic principle of TOD is that the development of a region is centered on the transit point. By developing a dense, multipurpose, and pedestrianized area, TOD aims to reduce dependence on motor vehicles [8]. TOD has the potential to increase the value of transport projects, in which the increasing value of land is affected by improved accessibility. On the other hand, land development also has the potential to increase the value of land, and it can be used as well as to increase property income that can help finance the transit system [9].

Several studies that have been done mainly focused on 
the analysis of the impacts and advantages of the implementation of TOD, particularly the benefits brought by the improved accessibility [10]. However, since the idea of using TOD to reduce automobile dependency is still new in Indonesia [7,11], therefore its implementation has not yet considered the impact of property value increase related to its proximity to the train station (transit system). In Asia, particularly in Japan, the implementation of TOD can generate revenue of $33.5 \%$ for real estate and $20.2 \%$ for retail [3]. Meanwhile, in Wuhan (China), the value increase of the property located near TOD area affected by the existence of rail transport for residential is $6.6 \%$, for commercial is $14.7 \%$, and for office is $11.6 \%$ [12]. In Kuala Lumpur, the value increase of residential property as the effect of LRT existence in the area is approximately $62.1 \%$ [13]. Meanwhile, in America, the price of residential property relating to the effect of LRT to the area of Phoenix TOD had been raised about 25\% [14]. The value increase of residential property in San Diego due to the effect of LRT is in the range of $3.8 \%-17.3 \%$ [15]. In Europe, particularly in the city of Lisbon (Portugal), the value increase of residential property near the TOD area resulting from the LRT impact is $15.17 \%$ [16].

As a concept of transport development that synergizes with spatial aspects to accommodate new growth, TOD strengthens the residential environment through the optimization of the mass public transportation networks, such as bus and train, making it easier for city residents to access city resources [17].

The development of TOD area at the Jabodebek LRT line in Indonesia (Jabodebek TOD) at the time of this writing is in its construction phase. This is done simultaneously with the construction of the Jabodebek LRT that will cross through those TOD areas. There are four Jabodebek TOD areas that will be investigated in this study, namely Bekasi Timur, Cibubur, Ciracas, and Jaticempaka.

As can be seen in Table 1, Bekasi Timur TOD is built on an area of 5 hectares with a total floor area of 178,100 square meters, most of which are intended for residential and retail/commercial. Meanwhile, Cibubur TOD is built on an area of 1.5 hectares with a total floor area of 55,588 square meters, $94 \%$ of which are intended for residential, and the remaining $6 \%$ is intended for retail/commercial. This TOD area has a floor area ratio (FAR) of 3,76 and coverage building ratio (CBR) of 30\%, which is the highest among the other investigated TOD areas. Furthermore, Ciracas TOD has a total area of 122,24 hectares with a total gross floor area (GFA) of 286,710 square meters, $72 \%$ of which are intended for residential. The last one is Jaticempaka TOD, which has a total area of 53,574 square meters and a total GFA of 138,007 square meters. However, the designs of these current TOD areas developed within the range of about 400 meters from the LRT stations are dedicated only to developing high-rise apartments for residential.

The main concern of this research is the value increase of different property types that include residential, commercial, and office that are affected by accessibility and the proximity to the LRT station. The percentage of the property value increase will be based on the coefficient value obtained from the Hedonic Price Modeling (HPM) equation. HPM is a method used to investigate property value and to measure the effects of the proximity to the rail station to the property value $[18,19]$. The obtained HPM value will be used as the coefficient that affects the property value increase, which corresponds to the types of property within the Jabodebek TOD Area.

Table 1. Jabodebek TOD design concepts

\begin{tabular}{|c|c|c|c|c|}
\hline Category & Bekasi Timur & Cibubur & Ciracas & Jaticempaka \\
\hline Land Area $\left(\mathrm{m}^{2}\right)$ & 50,000 & 15,000 & 122,239 & 53,574 \\
\hline Gross Floor Area $\left(\mathrm{m}^{2}\right)$ & 178,100 & 55,588 & 286,710 & 138,007 \\
\hline Semi Gross Area $\left(\mathrm{m}^{2}\right)$ & 123,800 & 38,912 & 184,956 & 118,176 \\
\hline Residential $\left(\mathrm{m}^{2}\right)$ & 150,000 & 45,000 & 206,612 & 116,266 \\
\hline Studio (Unit) & 4,500 & 1,500 & 6,000 & 3,431 \\
\hline 1 BR (Unit) & - & - & - & 651 \\
\hline 2 BR (Unit) & 900 & 300 & 1,075 & 208 \\
\hline Retail/Commercial $\left(\mathrm{m}^{2}\right)$ & 10,000 & 3,500 & 20,292 & 20,600 \\
\hline
\end{tabular}

Source: Document of Jabodebek TOD Feasibility Study 


\subsection{HPM Coefficient of Benchmark TODs}

The effects of the proximity to the transit station are very significant to Wuhan TOD. The remarkable value increase of residential property is obtained at a radius of $200-300$ meters from the station with a coefficient value of $6.6 \%$. The highest increase for commercial property is obtained at a radius of 200-300 meters from the station with a coefficient value of $14.7 \%$. On the other hand, the maximum increase for office property is obtained at a radius of 500-600 meters from the station with a coefficient value of $11.6 \%$ (see Table 2).

Table 2. Hedonic Model Impact of Line 2 MRT in Wuhan, China

\begin{tabular}{|c|c|c|c|}
\hline \multirow{2}{*}{ Distance to Station (m) } & Residential & Commercial & Office \\
\cline { 2 - 4 } & \multicolumn{3}{|c|}{ Coefficient } \\
\hline Ring 0-100 & 0.002 & 0.083 & 0.094 \\
\hline Ring 100-200 & 0.064 & 0.061 & 0.063 \\
\hline Ring 200-300 & 0.066 & 0.147 & 0.068 \\
\hline Ring 300-400 & 0.013 & & 0.106 \\
\hline Ring 400-500 & 0.031 & & 0.074 \\
\hline Ring 500-600 & 0.029 & & 0.116 \\
\hline Ring 600-700 & 0.034 & & \\
\hline Ring 700-800 & 0.029 & & \\
\hline Ring 800-900 & 0.01 & & \\
\hline Ring 900-1,000 & 0.052 & & \\
\hline
\end{tabular}

Source: Zhang [12]

The value increase for residential property in Kuala Lumpur TOD is strongly influenced by the floor area and the number of bedrooms by $62.1 \%$ and $24 \%$, while the proximity to hospitals and schools is only $5.1 \%$ and $7.3 \%$ (see Table 3).

Table 3. Hedonic Models Impact of LRT in Kuala Lumpur, Malaysia

\begin{tabular}{|l|c|}
\hline Variable & HPM Coefficient \\
\hline Design / Structure & \\
\hline Floor Area (sqf) & 0.621 \\
\hline Bedroom & 0.240 \\
\hline Location/Accessibility & \\
\hline Proximity to CBD & -0.473 \\
\hline Proximity to Industry & 0.058 \\
\hline Neighborhood/Environment & \\
\hline Proximity Hospital & 0.051 \\
\hline Proximity to school/University & 0.073 \\
\hline
\end{tabular}

Source: Dziauddin [13]

The research done on the hedonic price model in Santa Clara (California, USA) aimed to calculate the rise in the price of office and commercial land (see Table 4). The variables are grouped into three categories: proximity to train/highway, accessibility and location, and neighborhood quality proxies.
Table 4. Hedonic Model in Santa Clara, California USA

\begin{tabular}{|l|c|}
\hline \multicolumn{1}{|c|}{ Variable } & HPM Coefficient \\
\hline Rail/Highway Proximity & \\
\hline LRT station within $1 / 4$ mile & 4.062 \\
\hline CalTrain Station within $1 / 4$ mile & 25.430 \\
\hline Freeway within $1 / 2$ mile & -1.881 \\
\hline Accessibility \& Location & \\
\hline Regional labor force accessibility & 1.538 \\
\hline Downtown San Jose & 19.183 \\
\hline Neighborhood Quality Proxies & \\
\hline Building Values & 0.086 \\
\hline Household Income & 1.410 \\
\hline
\end{tabular}

Source: Cervero [22]

Lisbon TOD presents a hedonist pricing model to assess the relationship between transportation accessibility and property values with the aim of developing a financing scheme in the development of public transport in Portugal (see Table 5). The hedonic pricing model is estimated based on an online realtor database (Imokapa Vector). The preparation of models takes the characteristics of structural, environmental, and property accessibility attributes into account. Accessibility characteristics are divided into two types: local accessibility attributes and system accessibility attributes.

Table 5. Hedonic model impact of LRT in Lisbon, Portugal

\begin{tabular}{|l|c|}
\hline Variable & HPM Coefficient \\
\hline Design / Structure & 0.0165 \\
\hline Floor Area (sqf) & 0.0432 \\
\hline Bedroom & 0.1248 \\
\hline Location/Accessibility & 0.1517 \\
\hline $\begin{array}{l}\text { Proximity to Metro station ( }<10 \text { minutes } \\
\text { walking to the station) }\end{array}$ & 0.131 \\
\hline $\begin{array}{l}\text { Proximity to Rail station ( }<10 \text { minutes } \\
\text { walking to the station) }\end{array}$ & 0.938 \\
\hline Neighborhood/Environment & 0.425 \\
\hline $\begin{array}{l}\text { Education index (Number of undergraduate } \\
\text { educated at a radius of 500 m) }\end{array}$ & $\begin{array}{l}\text { Entropy index (Affordability on foot at a } \\
\text { distance of 500 m) }\end{array}$ \\
\hline
\end{tabular}

Source: Martínez [16]

\section{Methods}

While this research uses TOD development at the Jabodebek LRT line as the case study, TOD developments in Wuhan (China), Kuala Lumpur (Malaysia), Lisbon (Portugal), and California (USA) are used as the benchmarks evaluating the HPM coefficient value. The selection of these TOD developments was based on the consideration that these four areas are urban development that is integrated with transit stations. Moreover, from the 
diversity of property types, it can be seen that these selected areas have both residential and non-residential buildings as its property. Besides, the geographical representation as in Asia, Europe, and America is considered as well.

In order to determine which HPM coefficient value from the four benchmarks that will be used, interviews with practitioners from the managerial level in the field of TOD are conducted. The suitability of the characteristics of the HPM variables from the benchmark TODs with the Jabodebek TOD will be obtained by weighting the interview results. The interview is conducted with two hierarchies, in which the first hierarchy is done to examine the weight comparison between compared criteria that will be used as the bases for weighting benchmark TODs as the alternatives, while the second one is to examine the weight comparison between the alternatives for every criterion in the first hierarchy. The criteria investigated in this interview are the characteristics of HPM, which include: Design/ Structure, Location/ Accessibility, Environment/ Neighborhood.

The result of the interviews will be weighted by employing a pairwise comparison matrix [20]. The experts will consider how large an element dominates the other elements according to the attributes provided by referring to a scale of 9 round numbers. The weighting of these criteria is needed to justify the extent of similarity and suitability to Jabodebek TOD. The hedonic coefficient from the benchmark TODs that has the maximum weight will be used as the reference to calculate the increase of property value in Jabodebek TOD. The basic hypothesis in calculating house prices in hedonic modeling is expressed as the willingness to pay for a set of characteristics [21].

Empirical studies generally classify the decisive variables into three characteristics. First, design/structural attributes that describe the physical characteristics of the property (e.g., number of building floors, number of bedrooms, swimming pool, and garage). Second, location attributes that include distance to the workplace, key facilities (e.g., shopping facilities), and road infrastructure and transportation access points (e.g., railway stations, subway stations, major roads, highways, and airports). Third, environmental/neighborhood attributes that show the characteristics of socioeconomic status of the property owners (income status and race composition), the environmental quality and environmental facilities, such as air pollution, water pollution, noise, aesthetic views, and proximity to recreation or public services (See Table 6).

The calculation of property income for residential, commercial, and office in the TOD area will use the investment feasibility criteria that include Net Present Value (NPV) and Internal Rate of Return (IRR) [23]. The life cycle cost (LCC) method will be employed to calculate the investment feasibility of TOD development. Data needed for LCC calculation includes the data of initial cost, operational, and maintenance costs, which are acquired from the document of Jabodebek TOD feasibility study.

Table 6. Characteristics of HPM variables

\begin{tabular}{|c|c|c|c|}
\hline No & Characteristic & Variables & References \\
\hline \multirow{3}{*}{1} & \multirow{3}{*}{ Design/Structure } & \# Floor & Zhang [12] \\
\hline & & \# Bedroom & Dziauddin [13] \\
\hline & & & Martínez [16] \\
\hline \multirow{4}{*}{2} & \multirow{4}{*}{ Location/ Accessibility } & Proximity to Main Road/Tol Access & Zhang [12] \\
\hline & & Proximity to LRT Station & Dziauddin [13] \\
\hline & & & Martínez [16] \\
\hline & & & Cervero [22] \\
\hline \multirow{4}{*}{3} & \multirow{4}{*}{ Environment/Neighborhood } & Green space ratio & Zhang [12] \\
\hline & & Proximity to School/University & Dziauddin [13] \\
\hline & & & Martínez [16] \\
\hline & & & Cervero [22] \\
\hline
\end{tabular}




\section{Discussion and Result}

\subsection{Characteristics of Jabodebek TOD}

From the aspect of the location, the four Jabodebek TOD areas are located in a strategic area of the city and close to toll road access or the city's main highway. In the aspect of design/structural, Jabodebek TOD is a mix use area with a superblock concept consisting of several building towers that are more than 15 floors high. The types of apartment development include the studio (21 square meters), 1-bedroom (36 square meters), and 2-bedroom (45-50 square meters) apartment types. While from the aspect of the environment, all TOD areas are close to favorite schools and universities.

\subsection{Characteristics of Benchmark TODs}

From the literature study done, it is found that in terms of design/structural aspects, the residential property of Wuhan TOD has an average height of 19 floors with three bedrooms per unit, Kuala lumpur TOD has an average area of 651 square feet with three bedrooms per unit. Lisbon TOD has 2 to 3 bedrooms per unit with an average number of 3-storey building floors and an average floor area of 100 square meters. Meanwhile, TOD California is a residential area intended for workers and laborers.

From location/accessibility aspects, Wuhan TOD is not only close to the station but also to the main city road, while Kuala Lumpur TOD is close to the CBD and industrial area. On the other hand, Lisbon TOD is not only close to the train station but also to the bus terminal. California TOD is located in the center of the industrial area.

In terms of environmental aspect, Wuhan TOD is located close to favorite elementary school and has a green space ratio of 35\%, while Kuala Lumpur TOD is not only located close to the favorite school/university but also to the hospital. Furthermore, Lisbon TOD is an area where the average population is of productive age. Meanwhile, the residents of the California TOD area have an income above $\$ 10,000$.

\subsection{Pair Wise Comparison: Determining the Similarities and Conformity to Jabodebek TOD Characteristics}

The results of the interview are analyzed using a pair comparison matrix. The weight for all criteria obtained from the first hierarchy is as seen in Table 7.

Table 7. Weight of Criteria - Pair Wise Comparison

\begin{tabular}{|c|c|}
\hline Criteria & Weight \\
\hline Design/Structure & 0.964 \\
\hline Location/ Accessibility & 0.856 \\
\hline Environment/Neighborhood & 1.577 \\
\hline
\end{tabular}

On the other hand, the weights of each alternative TOD based on the criteria are as table 8 .

Table 8. Weight of Alternative TOD

\begin{tabular}{|c|c|c|c|c|c|}
\hline & & \multicolumn{3}{|c|}{ Criteria } & \multirow{2}{*}{ Total Weight $[\mathrm{d}]$} \\
\hline & & Design/Structure [a] & Location/ Accessibility [b] & $\begin{array}{c}\text { Environment } \\
/ \text { Neighborhood }[\mathrm{c}]\end{array}$ & \\
\hline \multirow{4}{*}{ Alternative } & Wuhan & 0.510 & 0.545 & 0.577 & 1.868 \\
\hline & Kuala lumpur & 0.162 & 0.133 & 0.649 & 1.294 \\
\hline & Lisbon & 0.279 & 0.092 & 0.058 & 0.440 \\
\hline & California & 0.049 & 0.230 & 0.115 & 0.426 \\
\hline
\end{tabular}

The total weight ((d) in Table 8) is obtained from multiplying the weight of alternative's matrix ([a], [b], and [c] in Table 8) with the weight of criteria (second column in Table 7).

Based on the analysis result of pairwise comparison matrixes, the highest to lowest weights obtained are 1,868 for Wuhan, 1.294 for Kuala Lumpur, 0.440 for Lisbon, and 0.426 for California. Since Wuhan has a higher weight than the other three, thus its hedonic modeling coefficient will be used as a hedonic increase coefficient for the Jabodebek TOD. 


\subsection{IRR and NPV of Jabodebek TOD}

The initial cost for the development of Jabodebek TOD acquired from its feasibility study document consists of the land acquisition cost, development cost of supporting infrastructure (access road, drainage system, etc.), construction cost, construction cost, licensing fee, professional fee (construction planners and management). Details of the initial cost of Jabodebek TOD development can be seen in Table 9.

The operational cost is about $5 \%$ of the annual income, and the insurance cost is $0,2 \%$ of the land and construction asset values.

Revenues are derived from the sales of residential and commercial units, where each residential unit has different prices determined by its kind (studio, 1-bedroom, 2- bedroom) and location, assuming that the sales rate estimated at 25-30 units per month. The detail of the prices is attained from the data on the feasibility study of Jabodebek TOD for the property type, and the residential property type can be seen in Table 10 .

Table 9. Intial Cost Pembangunan TOD Jabodebek

\begin{tabular}{|c|c|c|c|c|}
\hline Item & $\begin{array}{c}\text { Ciracas } \\
\text { (Million Rupiah) }\end{array}$ & $\begin{array}{c}\text { Bekasi Timur } \\
\text { (Million Rupiah) }\end{array}$ & $\begin{array}{c}\text { Cibubur } \\
\text { (Million Rupiah) }\end{array}$ & $\begin{array}{c}\text { Jaticempaka } \\
\text { (Million Rupiah) }\end{array}$ \\
\hline Land Acquisition & 348.431 & 125.000 & 100.620 & 300.651 \\
\hline Supporting Infrastructure & 103.562 & 64.237 & 11.013 & 146.073 \\
\hline Construction Cost & $1,664.477$ & 917.683 & 412.783 & $1,076.721$ \\
\hline Licensing Fee & 57.281 & 43.725 & 18.907 & 53.600 \\
\hline Professional Fee & 87.134 & 19.638 & 9.980 & 29.725 \\
\hline Total & $2,260.885$ & $1,170.283$ & 553.303 & $1,606.770$ \\
\hline
\end{tabular}

Table 10. Property price in Jabodebek TOD

\begin{tabular}{|c|c|c|c|c|}
\hline & Ciracas & Bekasi Timur & Cibubur & Jaticempaka \\
\hline \multicolumn{5}{|c|}{ Sell Price (Million Rupiah/Unit) } \\
\hline Studio & 334.110 & 242.550 & 406.560 & 369.215 \\
\hline 1BR & & & & 553.822 \\
\hline 2BR & 668.220 & 415.000 & 609.840 & 738.430 \\
\hline \multicolumn{5}{|c|}{ Rent price (Million Rupiah /sqm per year) } \\
\hline Retail & 9.450 & 9.450 & 10.445 & 9.758 \\
\hline
\end{tabular}

Referring to the HPM of the benchmark TOD, the hedonic coefficient value of Jabodebek TOD is translated into the following (See Table 11).

Table 11. The Coefficient of Hedonic Jabodebek TOD

\begin{tabular}{|c|c|c|c|}
\hline \multirow{2}{*}{ Distance to Station $(\mathrm{m})$} & Residential & Commercial & Office \\
\cline { 2 - 4 } & $(\alpha)$ & $(\beta)$ & $(\gamma)$ \\
\hline $000-100$ & $-0,002$ & 0,083 & 0,094 \\
\hline $100-200$ & 0,064 & 0,061 & 0,063 \\
\hline $200-300$ & 0,066 & 0,147 & 0,068 \\
\hline $300-400$ & 0,013 & - & 0,106 \\
\hline
\end{tabular}

The hedonic coefficient for properties located at a radius of 200 - 300 meters from LRT station is used as the basis to increase the property income in the Jabodebek TOD. , The selection of a 200-300 meters radius, is in accordance with the information given in the feasibility study, in which the property of Jabodebek TOD is located in a radius of 200-300 meters from the LRT station. The Net Present Value (NPV) and Internal Rate of Return (IRR) calculation methods are used as instruments to measure the financial feasibility of developing Jabodebek TOD areas, including Bekasi Timur, Cibubur, Ciracas, and Jaticempaka. The interest rate used is 9,8\%, which refers to the rate published by Bank Indonesia, with a tax rate of $20 \%$. 
The hedonic price increase formula used in the calculation is as follows:

1. $\mathrm{P} h$ Residential:

$$
\mathrm{Po}+(\alpha \times \mathrm{Po})
$$

2. $\mathrm{P} h$ Retail/Commercial:

$$
\mathrm{Po}+(\beta \times \mathrm{Po})
$$

3. Ph Office:

$$
\mathrm{Po}+(\gamma \times \mathrm{Po})
$$

Where:

$\mathrm{Po}=$ Property prices

$\mathrm{P} h=$ The prices of hedonic influences

$\alpha=$ Residential hedonic coefficient

$\beta=$ Retail/commercial hedonic coefficient

$\gamma=$ Office hedonic coefficient

Based on the calculation of the magnitude of the sales revenue of the property unit, the feasibility of property investment in each TOD area is calculated. The results of the calculation of the NPV and IRR values with and without the hedonic effects indicate that investments are feasible and can provide an increase to the income of all Jabodebek TOD

\begin{tabular}{|c|c|c|c|c|c|c|c|c|c|}
\hline & & \multicolumn{2}{|c|}{ Ciracas } & \multicolumn{2}{|c|}{ Bekasi Timur } & \multicolumn{2}{|c|}{ Cibubur } & \multicolumn{2}{|c|}{ Jaticempaka } \\
\hline \multicolumn{2}{|l|}{ TOD } & $\begin{array}{c}\text { NPV } \\
\text { (Billion } \\
\text { Rupiah) } \\
\end{array}$ & $\begin{array}{l}\text { IRR } \\
(\%)\end{array}$ & $\begin{array}{c}\text { NPV } \\
\text { (Billion } \\
\text { Rupiah) }\end{array}$ & $\begin{array}{l}\text { IRR } \\
(\%)\end{array}$ & $\begin{array}{c}\text { NPV } \\
\text { (Billion } \\
\text { Rupiah) } \\
\end{array}$ & $\begin{array}{l}\text { IRR } \\
(\%)\end{array}$ & $\begin{array}{c}\text { NPV } \\
\text { (Billion } \\
\text { Rupiah) } \\
\end{array}$ & $\begin{array}{l}\text { IRR } \\
(\%)\end{array}$ \\
\hline \multirow{2}{*}{$\begin{array}{l}\text { Influence of } \\
\text { hedonic benefit }\end{array}$} & Without & 253.489 & 10.99 & 9.716 & 9.94 & 28.826 & 11.82 & 222.386 & 11.30 \\
\hline & With & 414.534 & 11.70 & 84.013 & 11.01 & 152.975 & 19.51 & 330.364 & 12.01 \\
\hline
\end{tabular}
areas (See Table 12).

Table 12. Investment Feasibility Analysis of TOD Jabodebek

\section{Conclusions}

Based on the benchmark studies to TOD areas in some cities in the world, investigation using hedonic price modeling shows that there is an increase in property value resulted from the improved accessibility as the impact of the existence of rail-based transportation in the TOD area. The increased value in hedonic prices varies in each benchmarking location. In the benchmark used for value increase, Wuhan, the variable of proximity to the train station, has a very significant effect on the property value increase exercising different coefficients for each property type. For residential property, a significant increase is obtained at a radius of 200-300 meters with an increase coefficient value of 0.066 . For commercial property, the highest increase is obtained in a 200-300 meters radius with a coefficient value of 0.147 . While for the office property, the highest increase is obtained at the radius of 200-300 meters, with a coefficient value of 0.068 . The impact of the rail transit system on residential and commercial property in Jabodebek TOD is that there is an increase in prices of residential and commercial properties.

This finding makes optimizing the revenue from rising property selling prices impacted by the accessibility in the TOD area possible. This is in line with Cervero [15] which stated that with hedonic modeling in Los Angeles, USA, the impact of heavy rail and light rail could raise housing prices by $14.2 \%$ due to the proximity to the stations. Likewise, in Izmir (Turkey) [24], an increase of $\$ 250-300 /$ meter in the price of housing located close to the train station was obtained with HPM. It is also the case with what Chalermpong [25] declared that there is a rise in the house price of $\$ 10 /$ meter as the result of the proximity to the train station in Bangkok (Thailand).

It is found that due to the influence of the hedonic coefficient, the property income of Ciracas TOD is 414.5 billion rupiah with an internal rate of return (IRR) of $11.7 \%$, the property income of Bekasi Timur TOD is 84 billion rupiah with IRR of $11.01 \%$, the property income of Cibubur TOD is 152.97 billion rupiah with IRR of $19.51 \%$, and the property income of Jaticempaka TOD is 330.36 billion with IRR of $12.01 \%$. It can be concluded that compared to the initial value before using the coefficient of HPM, the increase of property value can increase the IRR of about $0.17 \%$ to $7.69 \%$ higher, while the NPV can be increased about 1.5 to 8 times.

From the findings of this study, the influence of the hedonic coefficient can be considered as a significant measure in the optimization of property value in the development of a TOD. Therefore it is recommended that further research can examine the proportion of land use in TOD to increase both property income and transit income, 
considering that TOD is a business model that combines rail transportation with the property.

\section{Acknowledgements}

The authors would like to convey sincere gratitude for Universitas Indonesia and the Ministry of Higher Education, the Republic of Indonesia, for the research grant.

\section{REFERENCES}

[1] Phoong SY, Phoong SW, Moghavvemi S, Phoong KH. User perception on urban light rail transit. Civ Eng Archit 2019;7:43-9. https://doi.org/10.13189/cea.2019.071405.

[2] Berawi MA, Susantono B, Miraj P, Gunawan, Husin AE. Conceptual design of sunda strait bridge using value engineering method. Proc. Int. Conf. Value Eng. Manag. Innov. Value Methodol. ICVEM 2012, 2012.

[3] Suzuki H, Murakami J, Hong Y-H, Tamayose B. Financing transit-oriented development with land values: Adapting land value capture in developing countries. The World Bank; 2015.

[4] Berawi MA, Zagloel TYM, Berawi ARB, Abdurachman Y. Feasibility analysis of trans-sumatera toll road using value engineering method. Int J Technol 2015. https://doi.org/10. 14716/ijtech.v6i3.1475.

[5] Berawi MA, Miraj P, Berawi ARB, Gunawan, Mikaelse K. Improving toll road feasibility: Route development and cost estimation. AIP Conf. Proc., vol. 1977, 2018. https://doi.or g/10.1063/1.5042972.

[6] Berawi MA. Improving Feasibility of High-Speed Train Project: Creating Added Value. Mod. Railw. Eng., 2018. https://doi.org/10.5772/intechopen.74288.

[7] Berawi MA, Ibrahim BE, Gunawan, Miraj P. Developing a conceptual design of transit-oriented development to improve urban land use planning. J Des Built Environ $2019 ; 19$.

[8] Cervero R, Kockelman K. Travel demand and the 3Ds: Density, diversity, and design. Transp Res Part D Transp Environ 1997. https://doi.org/10.1016/S1361-9209(97)000 $09-6$

[9] Medda F. Land value capture finance for transport accessibility: A review. J Transp Geogr 2012.https://doi.or g/10.1016/j.jtrangeo.2012.07.013.

[10] Cervero R, Ferrell C, Murphy S. Transit-Oriented Development and Joint Development in the United States: A Literature Review. Res Results Dig 2002.

[11] Sulistyaningrum S, Sumabrata J. Transit Oriented Development (TOD) index at the current transit nodes in Depok City, Indonesia. IOP Conf. Ser. Earth Environ. Sci., vol. 126, 2018. https://doi.org/10.1088/1755-1315/126/1/0 12217.
[12] Zhang M, Xu T. Uncovering the Potential for Value Capture from Rail Transit Services. J Urban Plan Dev 2017; 143: 04017006. https://doi.org/10.1061/(ASCE)UP.1943-5444. 0000383.

[13] Dziauddin MF, Powe N, Alvanides S. Estimating the Effects of Light Rail Transit (LRT) System on Residential Property Values Using Geographically Weighted Regression (GWR). Appl Spat Anal Policy 2015. https://doi.org/10.1007/s1206 1-014-9117-z.

[14] Golub A, Guhathakurta S, Sollapuram B. Spatial and Temporal Capitalization Effects of Light Rail in Phoenix: From Conception, Planning, and Construction to Operation. J Plan Educ Res 2012. https://doi.org/10.1177/0739456X1 2455523.

[15] Cervero R, Duncan M. Land Value Impacts of Rail Transit Services in Los Angeles County 2002.

[16] Martínez LM, Viegas JM. Effects of transportation accessibility on residential property values: Hedonic price model in the Lisbon, Portugal, metropolitan area. Transp Res Rec 2009. https://doi.org/10.3141/2115-16.

[17] Pongprasert P, Kubota H. TOD residents' attitudes toward walking to transit station: a case study of transit-oriented developments (TODs) in Bangkok, Thailand. J Mod Transp 2019; 27: 39-51. https://doi.org/10.1007/s40534-018-0170 -1 .

[18] Seo K, Salon D, Kuby M, Golub A. Hedonic modeling of commercial property values: distance decay from the links and nodes of rail and highway infrastructure. Transportation (Amst) 2019; 46: 859-82. https://doi.org/10.1007/s11116018-9861-z.

[19] Berawi MA, Suwartha N, Kurnia K, Gunawan, Miraj P, Berawi ARB. Forecasting the land value around commuter rail stations using Hedonic price modeling. Int $\mathrm{J}$ Technol 2018;9. https://doi.org/10.14716/ijtech.v9i7.2589.

[20] Kou G, Ergu D, Lin C, Chen Y. Pairwise comparison matrix in multiple criteria decision making. Technol Econ Dev Econ 2016.https://doi.org/10.3846/20294913.2016.121069 4.

[21] Xiao Y. Urban morphology and housing market. Springer Geogr., 2017.

[22] Cervero R, Duncan M. Transit's value-added effects: Light and commuter rail services and commercial land values. Transp Res Rec 2002: 8-15. https://doi.org/10.3141/180502 .

[23] Berawi MA, Nabila A, Gunawan, Miraj P, Rahman HA, Berawi ARB. Analysis of life cycle cost and public-private partnership in the development of Walini City as technology park. Int J Technol 2018; 9. https://doi.org/10.1 4716/ijtech.v9i7.2588.

[24] Murat Celik H, Yankaya U. The impact of rail transit investment on the residential property values in developing countries: The case of Izmir Subway, Turkey. Prop Manag 2006. https://doi.org/10.1108/02637470610671604.

[25] Chalermpong S. Rail transit and residential land use in developing countries: Hedonic study of residential property prices in Bangkok, Thailand. Transp Res Rec 2007. https://doi.org/10.3141/2038-15. 